University of Nebraska - Lincoln

DigitalCommons@University of Nebraska - Lincoln

Biological Systems Engineering: Papers and

Publications

Biological Systems Engineering

$10-1-2021$

\title{
Inter-relationships between water depletion and temperature differential in row crop canopies in a sub-humid climate
}

\author{
Jasreman Singh \\ University of Nebraska-Lincoln, jasreman8@gmail.com \\ Yufeng Ge \\ University of Nebraska - Lincoln, yge2@unl.edu \\ Derek M. Heeren \\ University of Nebraska-Lincoln, derek.heeren@unl.edu \\ Elizabeth Walter-Shea \\ University of Nebraska-Lincoln, ewalter-shea1@unl.edu \\ Christopher M.U. Neale \\ University of Nebraska-Lincoln, cneale@nebraska.edu
}

See next page for additional authors

Follow this and additional works at: https://digitalcommons.unl.edu/biosysengfacpub

Part of the Bioresource and Agricultural Engineering Commons, Environmental Engineering Commons, and the Other Civil and Environmental Engineering Commons

Singh, Jasreman; Ge, Yufeng; Heeren, Derek M.; Walter-Shea, Elizabeth; Neale, Christopher M.U.; Irmak, Suat; Woldt, Wayne; Bai, Geng; Bhatti, Sandeep; and Maguire, Mitchell S., "Inter-relationships between water depletion and temperature differential in row crop canopies in a sub-humid climate" (2021).

Biological Systems Engineering: Papers and Publications. 777.

https://digitalcommons.unl.edu/biosysengfacpub/777

This Article is brought to you for free and open access by the Biological Systems Engineering at DigitalCommons@University of Nebraska - Lincoln. It has been accepted for inclusion in Biological Systems Engineering: Papers and Publications by an authorized administrator of DigitalCommons@University of Nebraska Lincoln. 


\section{Authors}

Jasreman Singh, Yufeng Ge, Derek M. Heeren, Elizabeth Walter-Shea, Christopher M.U. Neale, Suat Irmak, Wayne Woldt, Geng Bai, Sandeep Bhatti, and Mitchell S. Maguire 


\title{
Inter-relationships between water depletion and temperature differential in row crop canopies in a sub-humid climate
}

\author{
Jasreman Singh, ${ }^{1}$ Yufeng Ge, ${ }^{1}$ Derek M. Heeren, ${ }^{1}$ \\ Elizabeth Walter-Shea, ${ }^{2}$ Christopher M. U. Neale, ${ }^{1,3}$ \\ Suat Irmak, ${ }^{1}$ Wayne E. Woldt, ${ }^{1}$ Geng Bai, ${ }^{1}$ \\ Sandeep Bhatti, ${ }^{1}$ and Mitchell S. Maguire ${ }^{1}$
}

1 Department of Biological Systems Engineering, University of Nebraska-Lincoln, Lincoln, Nebraska, USA

2 School of Natural Resources, University of Nebraska-Lincoln, Lincoln, Nebraska, USA

3 Daugherty Water for Food Global Institute at the University of Nebraska,

Lincoln, Nebraska, USA

Corresponding author - J. Singh, Department of Biological Systems Engineering,

University of Nebraska-Lincoln, 114 L.W. Chase Hall, Lincoln, NE 68583-0726, USA.

Email jasreman.singh@huskers.unl.edu

\begin{abstract}
Irrigation has a great impact on global food security as it contributes to the majority of the world's agricultural food supply. It is essential to judiciously utilize water resources through efficient irrigation management since the majority of U.S. groundwater aquifers are rapidly depleting. Thus, quantification of the relationships between water depletion and environmental factors is important for understanding crop response to varying levels of water stresses that depletion can cause. The objectives of
\end{abstract}

Published in Agricultural Water Management 256 (2021) 107061

Copyright (C) 2021 Elsevier B.V. Used by permission.

doi:10.1016/j.agwat.2021.107061

Submitted 13 December 2020; revised 27 June 2021; accepted 30 June 2021; published

1 October 2021. 
this research were to: 1 ) investigate the relationship between root zone water depletion $\left(\mathrm{D}_{\mathrm{rw}}\right)$ and canopy temperature differential $(\Delta \mathrm{T})$ at different ranges of $\mathrm{D}_{\mathrm{rw}}$; and 2 ) develop upper (water stressed) and lower (non-water stressed) baselines for quantification of crop water stress index (CWSI) in a sub-humid climate. The research was conducted over maize and soybean during 2018, 2019, and 2020 growing seasons. Sensor node stations comprising of an infrared thermometer and three soil water sensors were installed at various sites over maize and soybean fields. $\Delta \mathrm{T}$ tends to increase with the increase in $\mathrm{D}_{\mathrm{rw}}$ when the range of Drw includes values greater than $170 \mathrm{~mm}$ for maize and values greater than $160 \mathrm{~mm}$ for soybean. The results indicate that $\Delta \mathrm{T}$ and $\mathrm{D}_{\mathrm{rw}}$ are unrelated until a soil-water depletion threshold is attained, and these $\mathrm{D}_{\mathrm{rw}}$ threshold values could be considered as indicators to trigger irrigation for efficient agricultural water management. To the best of the authors' knowledge, the research is the first to develop upper and lower CWSI baselines for east-central Nebraska. The baselines developed in this study could facilitate the quantification of CWSI for irrigation scheduling of maize and soybean in east-Central Nebraska. Future work should aim to investigate the potential in using $\mathrm{D}_{\mathrm{rw}}$ and/or $\Delta \mathrm{T}$ to determine efficient water allocation and if a threshold CWSI could be used for timing of irrigation to prevent yield loss.

Keywords: Root zone water depletion, Temperature differential, Crop canopy, Infrared thermometers, Stressed baselines, Irrigation

\section{Introduction}

Irrigated agriculture is a significant contributor towards global food security as it produces more than $40 \%$ of the world's production from less than 20\% of cultivated land (WWAP World Water Assessment Programme, 2012). According to the 2012 Census of Agriculture, irrigated farms represent $14 \%$ of all the U.S. farms. These irrigated farms contributed towards $38.6 \%$ of the U.S. farm sales ( $\$ 152.4$ billion) and about $50 \%$ of the U.S. crop sales ( $\$ 106.3$ billion), even though only $28 \%$ of harvested cropland was irrigated (Hellerstein et al., 2019). For a sustainable future, it is essential to judiciously use water for irrigation purposes since groundwater depletion is a rising concern with the majority of aquifers in the U.S. and globally being depleted rapidly (Konikow, 2013).

Efficient irrigation is a vital component of farm management. Excessive irrigation increases fertilizer and irrigation pumping costs along with additional nitrate leaching and greenhouse gas emissions. Inadequate soil water content limits transpiration and photosynthesis which leads to a hindrance in crop growth and yield (Doorenbos and Kassam, 1979). For the optimum utilization of water resources in water-limiting conditions, deficit irrigation can be used to optimize grain yield per unit 
of water (Geerts and Raes, 2009). Accurate and continuous determination of soil water quantity can improve agricultural water management by better informing the timing and depth of irrigation applications and reduce the likelihood of excessive or insufficient irrigation. One of the ways this can be accomplished is through an automated sensor-based irrigation scheduling system that monitors crop water deficit continuously. The system must be inexpensive and should have minimal interference with the field operations, and be simple to use.

Monitoring crop water stress continuously often requires a high number of sensors for the determination of soil and crop water status (Playán et al., 2014). Efficient irrigation scheduling is strongly based on the ability to accurately estimate the appropriate amount, timing, and location of water application. Infrared thermometry can be used to monitor crop stress continuously; it is non-destructive, and scalable from single plants to the whole field. Numerous studies have utilized infrared thermometers (IRTs) to obtain a dynamic scan of canopy temperature from which the trigger point for irrigation can be established (e.g., Candogan et al., 2013; DeJonge et al., 2015; Irmak et al., 2000; O'Shaughnessy et al., 2017, 2012; Payero and Irmak, 2006; Peters and Evett, 2008; Taghvaeian et al., 2012). IRTs can provide information on the timing of the irrigation application through the determination of the difference between crop canopy temperature and air temperature [i.e., temperature differential $(\Delta T)$ of canopy temperature $\left(T_{c}\right)$ and air temperature $\left(T_{a}\right)$, i.e., $\left.\left(T_{c}-T_{a}\right)\right]$, but the amount of irrigation to be applied is either fixed or informed through other methods such as soil water depletion.

Repeated non-destructive measurements of soil water status can be used to monitor water stress and does not confound soil spatial variability. Researchers have used recently developed electromagnetic sensors to monitor soil water content and have investigated the applicability of electromagnetic sensors in scheduling irrigation (Datta et al., 2018; Huang et al., 2017; Kukal et al., 2020; Lea-Cox et al., 2018; Ojo et al., 2014; Rudnick et al., 2015; Singh et al., 2018; Varble and Chávez, 2011).

Singh et al. (2020) used soil water content sensors to measure root zone soil water depletion $\left(D_{r w}\right)$ for the top $1 \mathrm{~m}$ soil profile and found that monitoring $D_{r w}$ using soil water content sensors offer promise as input for efficient irrigation management. A relationship between $\Delta T$ and $D_{r w}$ could offer information about the timing and amount of irrigation applications. The relation between crop water stress and soil water condition 
has been studies for decades (Evett et al., 2020). With the advent of portable IRTs, the temperature differential between crop leaf and canopy temperatures $\left(\Delta T_{\text {leaf }}\right)$ has been explored since the $1960 \mathrm{~s}$ as a means to describe the relationship between soil water status and plant water status (Fuchs and Tanner, 1966).

Some studies analyzed the relationships between leaf water potential and the $\Delta T$ (Ehrler et al., 1978a, 1978b; Gardner et al., 1981), but these relationships were not stable. An inverse relationship between temperature difference (leaf - air) and vapor pressure deficit (VPD) was observed by Ehrler (1973). Later, Jackson et al. (1977) defined a stress degree day index (SDD) as the temperature differential at midday; the cumulative SDD plotted alongside water depleted from the root zone indicated a relationship as did plotting the total water used versus SDD for winter wheat. It implied that there was a unique relationship between the accumulated SDD and soil profile water depletion. Furthermore, Jackson et al. (1981) and Idso et al. (1981b, 1981a) developed a crop water stress index (CWSI) which considered the energy balances of non-stressed and completely stressed crop canopies. The CWSI is defined as the temperature differential $(\Delta T)$ relative to the temperature difference between a well-watered canopy $\left(d T_{L L}\right)$ and of a non-transpiring canopy $\left(d T_{U L}\right)$. A correlation between the relative available water (instantaneous volumetric soil water content divided by volumetric water content at field capacity, $F_{c}$ ) and the CWSI was observed by Nielsen and Anderson (1989) for sunflower. The relationship was statistically significant with a quadratic regression curve and high coefficient of determination (0.89). Two different approaches to determine CWSI have been established: an empirical approach (Idso et al., 1981a) and a theoretical approach (Jackson et al., 1981). There are advantages with the empirical approach as it is dependent on only two variables (relative humidity and $T_{a}$ ) in addition to the $T_{c}$. Based on the empirical approach, $d T_{L L}$ is measured as a linear function of atmospheric vapor pressure deficit (VPD), and this relationship is known as non-water stressed baseline. Similarly, $d T_{U L}$ is estimated as the linear function of vapor pressure gradient, and the relationship is known as water stressed baseline. The limitation of empirical approach is that the non-water stressed baseline varies by crop, growth stage, and climatic condition. Therefore, a location-specific non-water stressed baseline should be developed for determination of CWSI (Nielsen, 1990). The relationship between the CWSI 
and soil water quantity (Barnes et al., 2000; Colaizzi et al., 2003; DeJonge et al., 2015; Taghvaeian et al., 2014, 2012) has been investigated with varying responses in different environments.

In order to address the concerns highlighted above, we performed field research on maize and soybean for three growing seasons and monitored $\mathrm{T}_{\mathrm{c}}$ and soil water content. The specific objectives of the study were to:

a) investigate the relationship between $\Delta T$ and the $D_{r w}$ for maize and soybean for multiple growing seasons and determine the potential variations of this relationships between the years,

b) develop upper (water stressed) and lower (non-water stressed) baselines for quantification of CWSI in maize and soybean in a subhumid climate (east-central Nebraska, USA), and

c) quantify CWSI for crops near $80 \%$ crop canopy cover to maturity during the three growing seasons and relate the seasonal CWSI for each replicate in 2018 and 2019 with the average yield from surrounding plots for the growing seasons, following the approach presented by Irmak et al. (2000).

\section{Materials and methods}

\subsection{Site and soil description}

A field experiment was conducted at the University of Nebraska's Eastern Nebraska Research and Extension Center (ENREC) near Mead, Nebraska $\left(41.165^{\circ} \mathrm{N}, 96.430^{\circ} \mathrm{W}\right)$ during the 2018,2019 , and 2020 growing seasons planted with maize in one section and soybean in another. The field size was nearly 53 ha, and was irrigated with a center pivot (Lindsay Corporation, Omaha, Nebraska, Zimmatic 8500). In 2018, the field was planted with soybean in the north half of the field and maize in the southern half, then rotated for each half in 2019, and rotated back for each half in 2020. Crops were planted in rows running approximately east-to-west at $0.76 \mathrm{~m}$ spacing, under no till management with residue cover from the previous seasons. Two soil types in the experimental field were silty clay loam and silt loam (Soil Survey Staff, 2020). Textural composition, organic matter content (OMC), bulk density $\left(\rho_{b}\right)$, and saturated paste extract electrical conductivity $\left(\sigma_{a}\right)$ were determined at 
Table 1 Mean \pm standard deviation of textural composition, organic matter content (OMC), bulk density $(\rho b)$, and saturated paste extract electrical conductivity $(\sigma a)$ of the soils at the study site as determined from three cores taken from node location sites at ' $\mathrm{F}$ ' and ' $\mathrm{J}$ ', respectively as shown in Fig. 1.

\begin{tabular}{lcccccc} 
Soil type & Sand (\%) & Silt (\%) & Clay (\%) & OMC (\%) & $\rho_{\mathrm{b}}\left(\mathrm{g} \mathrm{cm}^{-3}\right)$ & $\left.\sigma_{\mathrm{a}}(\mathrm{dS} \mathrm{m})^{-1}\right)$ \\
\hline Yutan silty clay loam & $19 \pm 2$ & $46 \pm 2$ & $35 \pm 2$ & $3.8 \pm 0.0$ & $1.35 \pm 0.06$ & $0.24 \pm 0.02$ \\
Fillmore silt loam & $17 \pm 1$ & $47 \pm 1$ & $37 \pm 1$ & $4.4 \pm 0.1$ & $1.29 \pm 0.02$ & $0.41 \pm 0.03$ \\
\hline
\end{tabular}

a soil depth of $0.15 \mathrm{~m}$ for the two different soil types at two locations (Table 1). Further description of the field site, soils, and irrigation system can be found in (Barker et al., 2018; Bhatti et al., 2020). For the study, maize and soybean fields were at $80 \%$ to full-canopy with over an abundance of soybean and maize stover and a soil untilled for more than three years in 2018.

\subsection{Experiment description}

Stationary sensor node stations (Fig. 2a and b) were established in maize and soybean for the three growing seasons. The sensor node stations were installed along the crop rows with the set of soil water content sensors under the crop row and the IRT was mounted over the crop row (Fig. 2a and b). The soil water content spatial variability was considered while determining the location of sensor node stations in the field in order to span around a wide range of available water capacity. The range of available water capacities for different locations in the field was determined in a past study (Miller et al., 2017). The soil samples were collected from two sites which were suspected to be the most different in terms of textural composition and organic matter content (Table 1). However, the soil spatial variability was not the focus of this study. The irrigation in the field was managed according to a different study. The irrigation treatments in the field during 2018, 2019, and 2020 growing seasons were variable rate irrigation, uniform irrigation and rainfed (Table 2). Variable rate irrigation was prescribed by using Spatial Evapotranspiration Modeling Interface (SETMI; Neale et al., 2012). A uniform irrigation was managed by monitoring soil water content through neutron probe during 2018 growing season (Bhatti et al., 2020) and soil water sensors during 2019 and 2020 growing seasons (Singh et al., 2021) in one plot for each crop. The irrigation treatments in this study were 
Table 2 The irrigation treatments for the individual replications as shown in Fig. 1 during 2018, 2019 , and 2020 study periods. The treatments were variable rate irrigation (VRI), uniform irrigation (U), and no-irrigation/rainfed (R).

\begin{tabular}{lcc} 
Crop & Maize & Soybean \\
\hline 2018 study period & & \\
Rep 1 & VRI & R \\
Rep 2 & R & VRI \\
Rep 3 & R & VRI \\
Rep 4 & VRI & VRI \\
2019 study period & & \\
Rep 1 & R & R \\
Rep 2 & VRI & VRI \\
Rep 3 & U & R \\
Rep 4 & VRI & U \\
2020 study period & & \\
Rep 1 & VRI & U \\
Rep 2 & $\mathrm{U}$ & $\mathrm{U}$ \\
Rep 3 & $\mathrm{R}$ & VRI \\
Rep 4 & $\mathrm{U}$ & $\mathrm{R}$ \\
\hline
\end{tabular}

designed for Singh et al. (2021) with the objective of sensor-based irrigation scheduling of maize and soybean. The different irrigation treatments performed similarly based on the observed yield. The cumulative irrigation for VRI and uniform treatments was within $10 \%$ of each other during 2018 and 2019 growing seasons. And the yields for variable rate irrigation and uniform irrigated treatments were significantly not different from each other for the three growing seasons. In short, the interrelationships determined in this study are not influenced by the different irrigation treatments. No irrigation was applied to rainfed plots in the study. More information about how the irrigation was prescribed at different locations in the field has been described in detail by Bhatti et al. (2020) and Singh et al. (2021). Four replications of sensor node stations were installed in maize and soybean during 2018, 2019, and 2020 growing seasons (Fig. 1). All the sensors were installed following manufacturer recommendations and allowed to acclimate with the surrounding soil and environment prior to the start of each growing season.

Each sensor node station was comprised of three soil water content sensors (Meter Environment's GS-1), and an infrared radiometer (IRT) sensor (Apogee Instruments SI-111, Logan, UT). Single-sensor soil water probes were installed into the walls of $0.15 \mathrm{~m}$ diameter auger-dug pits located directly underneath a single row of soybean/maize at a distance 


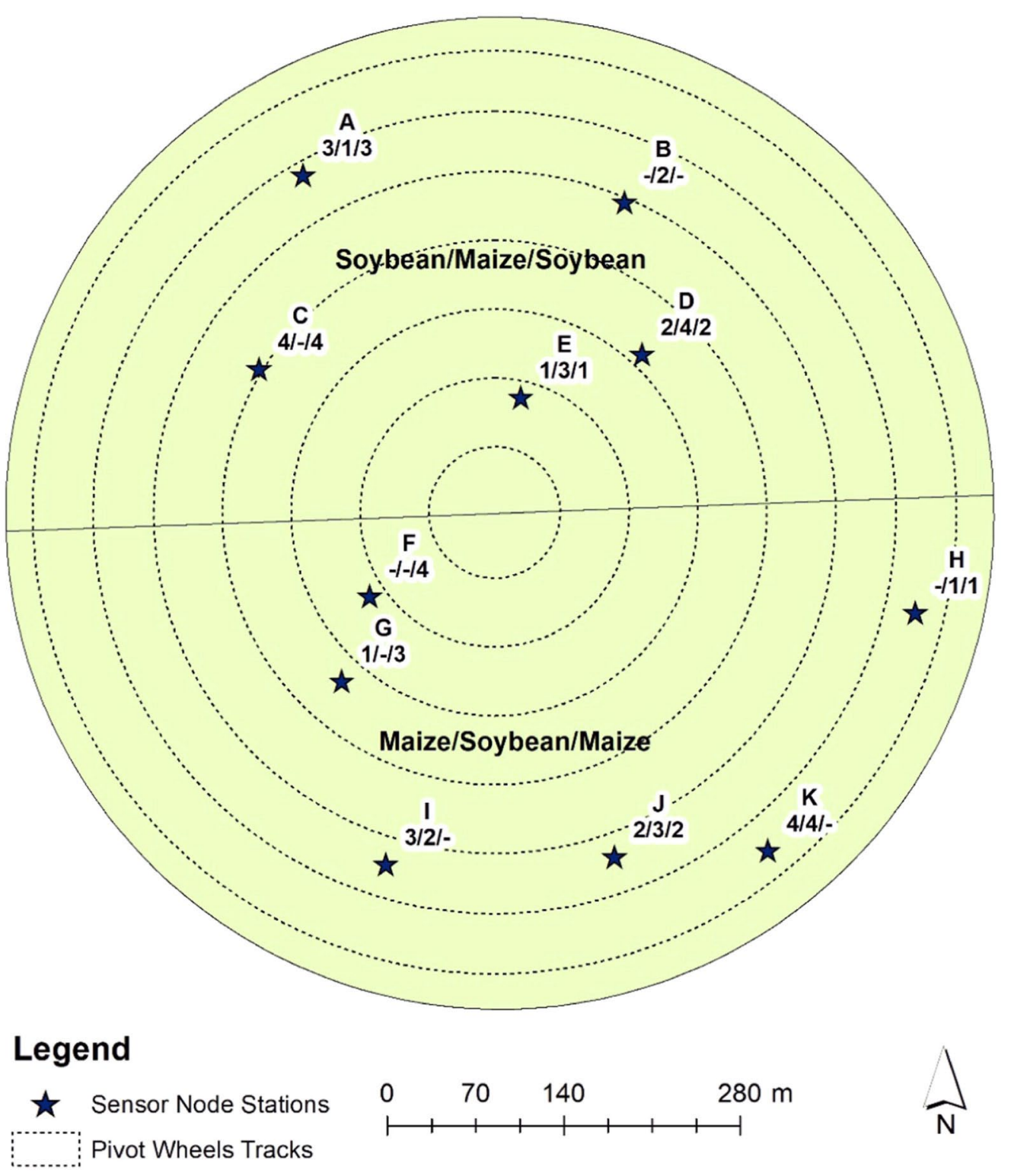

Fig. 1. Sensor node location and replication layout for the experiment during 2018 and 2019 study periods. Letters (A-J) inside the plot numbers indicate the location of the 11 sensor node stations in the field. Numerals along with the letters assigned to each sensor node stations denote the replication number allotted in 2018/2019/2020. In 2018, 2019, and 2020 there were 4 reps in maize and soybean, respectively. '-' in plot labels is used to indicate that the location was not used in the analysis for that year.

of $0.15 \mathrm{~m}$ from the maize/soybean row. The soil water content probes were inserted at a depth of $0.15 \mathrm{~m}, 0.46 \mathrm{~m}$, and $0.76 \mathrm{~m}$, respectively with the sensor prongs oriented horizontally in the pit (Fig. 2a). 


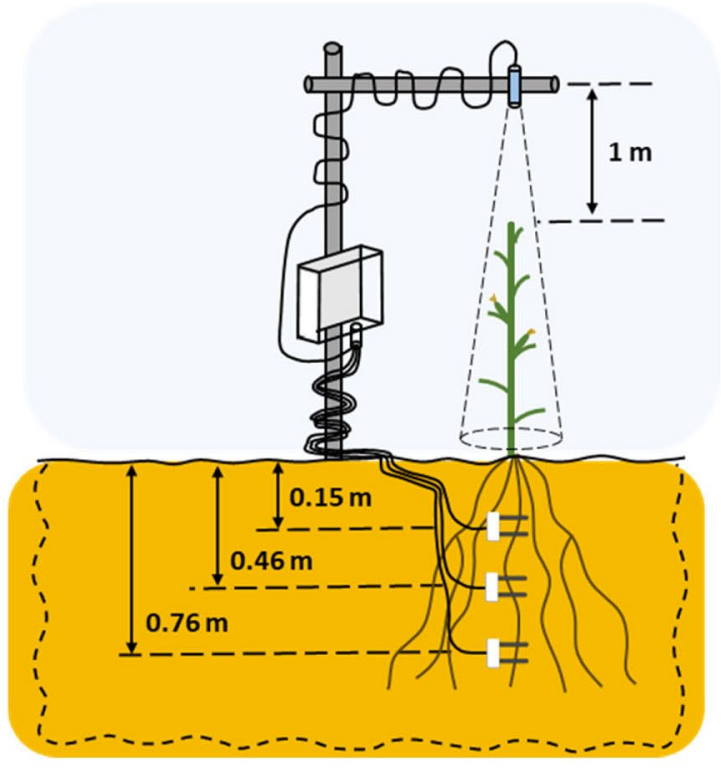

(a)

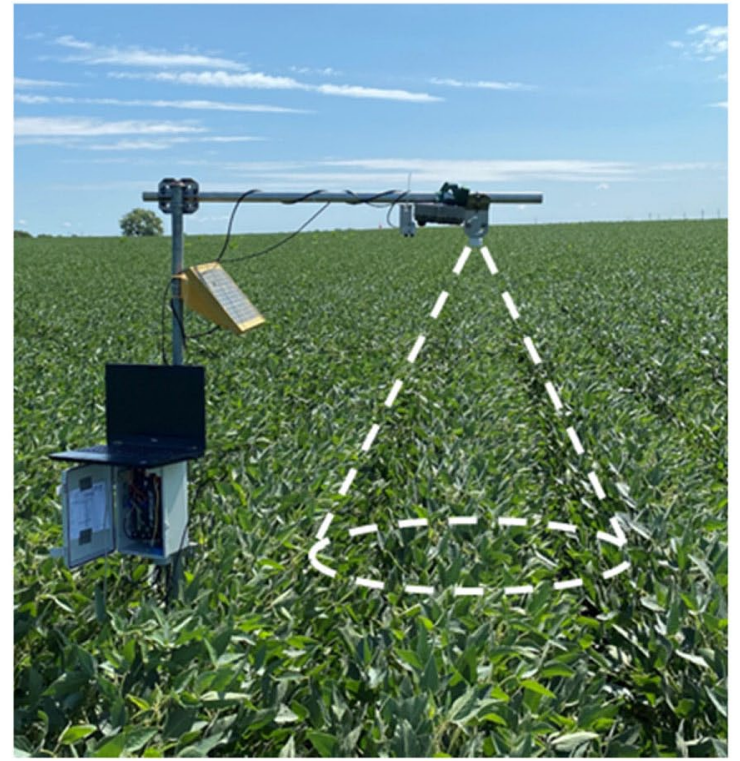

(b)

Fig. 2. (a) Illustration of sensor node station comprised of soil water sensors at 0.15 $\mathrm{m}, 0.46 \mathrm{~m}$, and $0.76 \mathrm{~m}$ below the crop row and an infrared radiometer sensing the crop canopy maintained $1 \mathrm{~m}$ over the top of the maize canopy; (b) Sensor node station comprising of infrared radiometer sensor sensing the soybean canopy from $2 \mathrm{~m}$ above the ground.

The IRT sensor was mounted at a constant height of $2 \mathrm{~m}$ above ground for soybean throughout the growing season (Fig. 2b). The IRTs in maize were mounted on an adjustable mast to account for the changing canopy height and maintained at a height difference of $1 \mathrm{~m}$ between the IRT and canopy top (adjusted every two weeks after tasseling). The IRT was oriented vertically looking downward from Nadir for all node stations. In order to minimize the contribution of the soil background to the IRT reading, the study period was restricted to crop canopy cover of $80 \%$ or greater. The output from the sensors were recorded every $15 \mathrm{~min}$ as an average with a sampling frequency of $5 \mathrm{~s}$.

Meteorological measurements of hourly averaged ambient air temperature and relative humidity (used for determination of VPD), and daily values of precipitation were obtained from the Nebraska State Climate Office stations under the Nebraska Mesonet program. Weather data were obtained from the Nebraska Mesonet Memphis $5 \mathrm{~N}$ station $\left(41.15^{\circ} \mathrm{N}\right.$, $96.417^{\circ} \mathrm{W}$; NSCO) (Shulski et al., 2018). This station was approximately 
$1 \mathrm{~km}$ southeast of the research field with sensor heights of $2 \mathrm{~m}$ above ground; Mesonet site location followed standard requirements. The sensors used at the meteorological weather stations are highly accurate and widely used for various applications.

The crop yield was measured using yield monitors installed on harvesters. Yield Editor Software version 2.0 (Agriculture Research Service, United States Department of Agriculture) was used to filter and clean yield data. The filtered yield was checked by the average yield obtained from the grain carts. The yield analysis was compiled based on the computed dry mass of crop grain yield. Yield for the areas surrounding the node stations were retrieved.

\subsection{Sensors}

\subsubsection{GS-1 soil water sensor}

GS-1 soil water sensor (METER Group Inc., Pullman, Wash.) is a recently developed capacitance and frequency domain technology based sensor with a rugged, durable design configured with two parallel waveguide rods (5.2 $\mathrm{cm}$ in length). The GS-1 sensor head contains the necessary firmware and electronics to generate an electromagnetic field in the surrounding medium to measure the dielectric constant. The sensor uses an oscillator running at $70 \mathrm{MHz}$ that charges in response to the dielectric constant of the surrounding material. Through a correlation of the measured dielectric constant to the apparent permittivity, and the permittivity to volumetric soil water content $\left(\theta_{v}\right.$ in $\left.\mathrm{m}^{3} \mathrm{~m}^{-3}\right), \theta_{v}$ is derived from the charge value ( $V_{\text {charge }}$ in $\mathrm{mV}$ ) provided by the sensor:

$$
\theta_{v}=4.94 \times 10^{-4} \times V_{\text {charge }}-0.554
$$

The sensor has a measurement volume of $430 \mathrm{~mL}$. A datalogger (CR1000, Campbell Scientific, Inc., Logan, Utah) was used to sample at a frequency of $5 \mathrm{~s}$ and record an average $\theta_{v}$ every $15 \mathrm{~min}$.

\subsubsection{SI-111 infrared radiometer}

SI-111 infrared radiometer (Apogee Instruments, Inc., Logan, Utah, USA) measures emitted infrared radiation (within an atmospheric window of 8-14 $\mu \mathrm{m}$ ) from which target surface temperature is remotely determined. This sensor has a $44^{\circ}$ field of view and $\pm 0.2{ }^{\circ} \mathrm{C}$ accuracy over the temperature range of -10 to $65^{\circ} \mathrm{C}$. The IRTs monitored 
temperatures of maize and soybean field surfaces continuously. The IRTs were maintained at a height of $1 \mathrm{~m}$ above the canopy throughout the growing season for maize (adjusted every two weeks after tasseling), resulting in a circular horizontal target around $0.513 \mathrm{~m}^{2}$ in size at the top of the canopy ( $80 \%$ or greater cover). The installation height for soybeans was $2 \mathrm{~m}$ from the ground surface and remained above the canopy at that height at all times. The maximum height of soybean was measured as $1.2 \mathrm{~m}$. The IRTs data were restricted to measurements when the crop canopy had $80 \%$ or greater coverage to minimize contribution of soil background temperature to the canopy temperature. The measured voltage $\left(V_{\text {measured }}\right.$ in $\mathrm{mV}$ ) is related to the temperature of the surface using the manufacturer's calibration:

$$
T_{c}=c_{2} \times\left(V_{\text {measured }}\right)^{2}+c_{1} \times\left(V_{\text {measured }}\right)+c_{0}
$$

The IRT sensors were calibrated by the manufacturer (Apogee Instruments, Inc.) and re-calibrated (once every two years) based on manufacturer's recommendations. The canopy temperatures $\left(T_{c}\right)$ along with the air temperature $\left(T_{a}\right)$ were measured by the datalogger (CR1000, Campbell Scientific, Inc., Logan, Utah) every $5 \mathrm{~s}$ and averaged and recorded at 1 min intervals.

\subsection{Analysis}

In this study, the root zone water depletion for the top $1 \mathrm{~m}$ soil profile $\left(D_{r w}\right.$, in $\left.\mathrm{mm}\right)$ and the temperature differential $\left(\Delta T=T_{c}-T_{a}\right)$ were analyzed with an emphasis on investigating the relationship between them. The $D_{r w}$ was determined using the difference between the soil field capacity $\left(F_{c^{\prime}}\right.$ in $\left.\mathrm{mm}\right)$ and the available root zone water depth $(A W D$, in $\mathrm{mm}$; i.e., the equivalent depth of water in the soil and is a function of $\theta_{v}$ and thickness of soil layer). $F_{c}$ was estimated based on the soil texture with a pedotransfer function (Saxton and Rawls, 2006) and the depth of root zone. The $F_{c}$ estimated were compared to past observed $F_{c}$ for the field site (Lo et al., 2017; Singh et al., 2020). The observed $F_{c}$ values were similar to the $F_{c}$ estimated using the pedotransfer functions, giving confidence to the values used in this study.

$$
\begin{aligned}
D_{r w}= & F_{c}-A W D \\
A W D= & \theta_{v(a t 0.15 \mathrm{~m})} \times 305 \mathrm{~mm}+\theta_{v(\text { at } 0.46 \mathrm{~m})} \times 305 \mathrm{~mm} \\
& +\theta_{v(\text { at } 0.76 \mathrm{~m})} \times 390 \mathrm{~mm}
\end{aligned}
$$


The root zone water depth for the top $1 \mathrm{~m}$ soil profile was determined using the depth weighted-average method from the observed $\theta_{v}$ reported by GS- 1 sensors installed at $0.15,0.46$, and $0.76 \mathrm{~m}$ depths for each location. It was assumed that the available water depth $(A W D)$ for the top $0.30 \mathrm{~m}$ of soil profile was represented as the product of $\theta_{v}$ at 0.15 $\mathrm{m}$ depth and $305 \mathrm{~mm}, A W D$ for the 0.30-0.61 $\mathrm{m}$ was represented as the product of $\theta_{v}$ at $0.46 \mathrm{~m}$ and $305 \mathrm{~mm}$, and $A W D$ for $(0.61-1.0 \mathrm{~m})$ as the product of $\theta_{v}$ at $0.76 \mathrm{~m}$ and $390 \mathrm{~mm}$. The maximum $\Delta T\left(T_{c}-T_{a}\right)$ within a diurnal period was generally observed during the mid-afternoon, i.e. around $1500 \mathrm{~h} C D T$, indicating the time of potential maximum $\Delta T$ during the day. Therefore, the analysis was limited to 1 min average temperature dataset retrieved at $1500 \mathrm{~h}, \mathrm{CDT}$ for the non-cloudy/nonprecipitation days during 2018, 2019, and 2020 growing seasons when the crop canopy was $80 \%$ or greater cover (i.e., from July to mid- September).

The crop water stress index (CWSI) provides an estimate of crop water status with respect to the minimum and maximum levels of stress that can occur due to an excess or deficiency of water. The first step in the estimation of CWSI was to develop the non-water-stressed and water-stressed baselines for both crops. CWSI is the comparison of the difference between measured canopy and air temperatures $\left(T_{c}-T_{a}\right.$ or $\left.\Delta T\right)$, and the lower $\left(d T_{L L}\right)$ and upper $\left(d T_{U L}\right)$ limits of canopy-air temperature differential.

$$
\text { CWSI }=\frac{\left(\Delta T-\mathrm{dT}_{\mathrm{LL}}\right)}{\left(\mathrm{dT}_{\mathrm{UL}}-\mathrm{dT}_{\mathrm{LL}}\right)}
$$

The lower $\left(d T_{L L}\right)$ and upper $\left(d T_{U L}\right)$ limit values were found under nonwater-stressed/irrigated conditions (minimum $\Delta T$ amongst variable rate irrigation or/and uniform irrigation treatments), and water-stressed/ rainfed conditions (maximum $\Delta T$ amongst rainfed treatments), respectively amongst the replications based on the approach of Jackson et al. (1981). The CWSI non-water stressed and water-stressed baselines for the maize and soybean were determined using an empirical approach with the combined data from the 2018, 2019, and 2020 growing seasons. The fundamental assumption for the empirical approach is that there is a linear relationship between $\mathrm{dT}_{\mathrm{LL}}$ and vapor pressure deficit (VPD) for a given non-water-stressed crop under a specific climatic condition:

$$
d T_{L L}=T_{c}-T_{a}=m \times(V P D)+b
$$




$$
V P D=\left[\frac{(100-R H)}{100}\right] \times\left[\frac{610.7 \times 10^{(7.5 T) /(237.3+T)}}{1000}\right]
$$

where " $m$ " and " $b$ " are the slope and intercept of the linear relationship, respectively (Eq. 6). The $V P D(\mathrm{kPa})$ was determined as shown in Eq. 7 from the relative humidity $(R H$, in $\%)$ and the ambient air temperature $\left(T\right.$, in $\left.{ }^{\circ} \mathrm{C}\right)$ values reported by the adjacent Nebraska Mesonet weather station. The values for $d T_{U L}$ were plotted against $V P D$ to determine the water-stressed (upper) baseline. Estimated CWSI at a single one-hour period (1500 h, CDT) was highly variable throughout the three growing seasons.

The $\Delta T$ was determined for each of the sensor node stations installed in maize and soybean. The relationship between the $\Delta T$ and $D_{r w}$ (Eq. 4) for maize and soybean was investigated through Analysis of variance (ANOVA) with a significance level of $\alpha=0.05$, conducted using the statistical computing language $\mathrm{R}$ ( $\mathrm{R}$ version 3.3.2, $\mathrm{R}$ Foundation for Statistical Computing, Wien, Austria). In addition, the difference in relationships for different ranges of $D_{r w}$ was assessed, and the relationship between $D_{r w}$ and $A W D$ was analyzed. The CWSI values were determined at various growth stages (from late vegetative to early maturity) for three maize and soybean growing seasons. Seasonal CWSI values were calculated for each replication for the 2018 and 2019 and then correlated with the average yield of the plots surrounding the sensor node location in each replication for maize and soybean for those two growing seasons. Since, we did not have the yield data for the 2020 growing season, we did not include the seasonal mean CWSI from 2020 in the analysis. The implications for agricultural water management were also discussed.

\section{Results}

\subsection{Comparison of temperature differential and root zone water depletion}

The cumulative rainfall for months May to October as recorded by the adjacent weather station was 608,610, and $260 \mathrm{~mm}$ in 2018, 2019, and 2020 , respectively. However, cumulative precipitation during the period of study, i.e., from July to mid-September (Fig. 3) was 272, 113, and 115 $\mathrm{mm}$ in 2018, 2019, and 2020 respectively. 

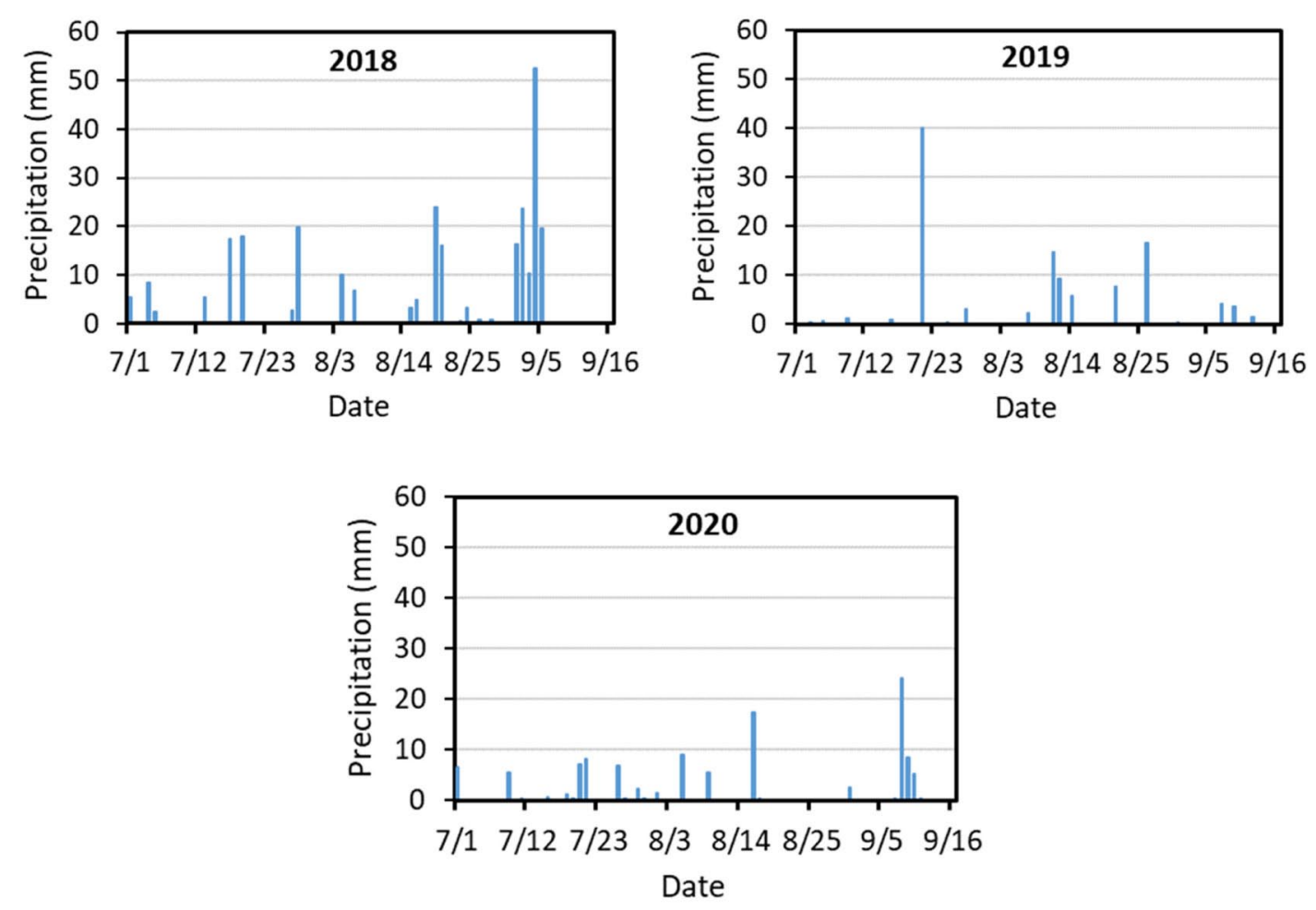

Fig. 3. Precipitation during mid to late growing season for the three study periods measured by the adjacent High Plains Regional Climate Center's Automated Weather Data Network station: Memphis $5 \mathrm{~N}\left(41.15^{\circ} \mathrm{N}, 96.417^{\circ} \mathrm{W}\right)$.

For the analyses in maize, four replications were considered for the 2018, 2019, and 2020 growing seasons in the different halves of the field. The observed $D_{r w}$ (Fig. 4) during the 2018 growing season was quite low $(<100 \mathrm{~mm})$ since a relatively high amount of precipitation $(272 \mathrm{~mm})$ was received and consequently more infiltration and root zone water storage during 2018 study period. The relationships between $\Delta T$ and $D_{r w}$ (Fig. 5) for the four replications during the 2018 growing season were tested statistically separately for each replication, and it was found that the linear/polynomial relationships were statistically non-significant (p-value $>0.05$ ) for all replications. In addition, the linear relationships for the four replications were not different from each other $(p>0.05)$ and yield lower coefficient of determination $\left(R^{2}\right)$ values, i.e. $R^{2} \leq 0.02$ (Table 3 ). However, the 2019 and 2020 study periods were drier than 2018 study period, resulting in higher $D_{r w}$ values than those of 2018 (Fig. 4 and Table 3). During 2019 study period, replications 1 and 4 yielded $D_{r w}$ values greater than $170 \mathrm{~mm}$ (Table 3 ). The linear equation relationships 

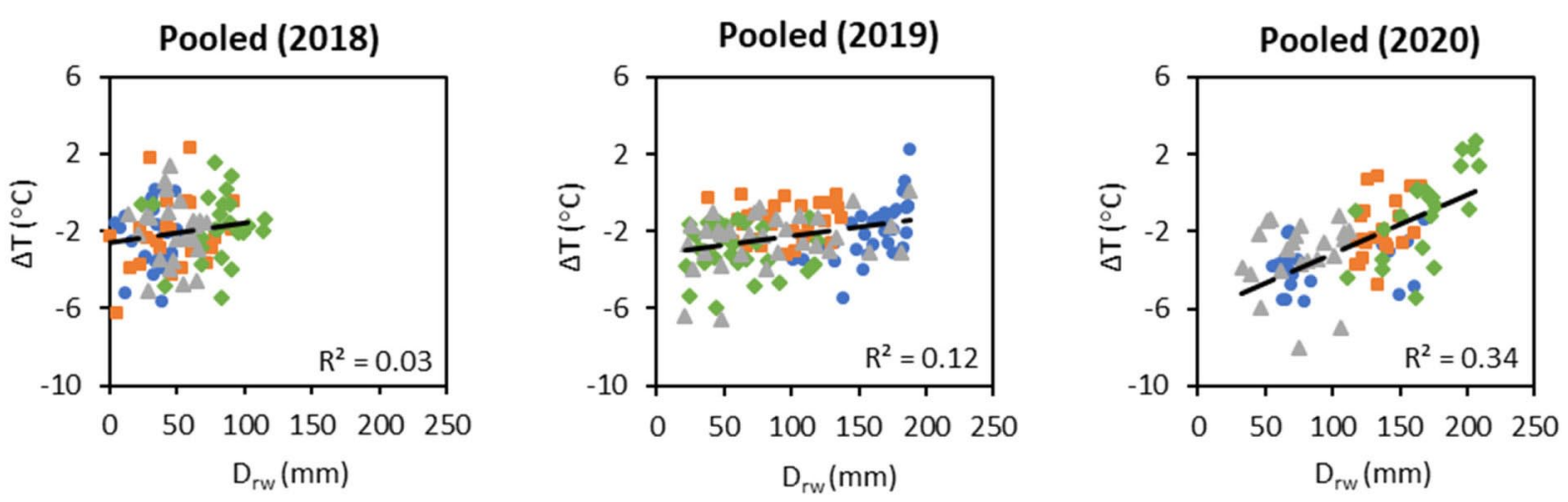

\section{- Replication 1}

\section{Replication 2 Replication 3}

\section{$\triangle$ Replication 4}

Fig. 4. Comparison of the temperature differential $(\Delta T$; canopy temperature - air temperature) and the root zone water depletion (Drw) for the four replications (pooled) in maize during 2018, 2019, and 2020 study periods.
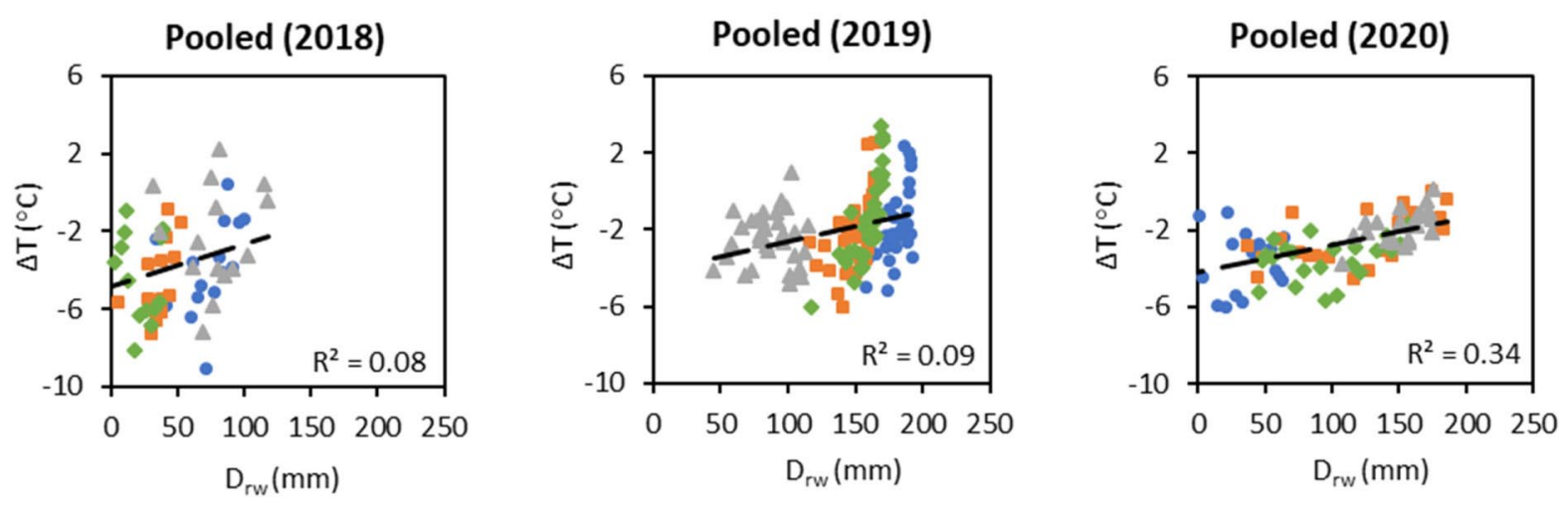

\section{- Replication 1}

\section{- Replication $2 \quad$ Replication 3}

$\triangle$ Replication 4

Fig. 5. The comparison of the temperature differential $(\Delta T$; canopy temperature - air temperature) and the root zone water depletion ( $D r w)$ for the four replications in soybean, respectively during the 2018,2019 , and 2020 study periods.

between $D_{r w}$ and $\Delta T$ were statistically significant for these replicates 1 and 4 (p-value $<0.05$ ). However, the observed relationships for replications 2 and 3 where the $D_{r w}$ values were not higher than $170 \mathrm{~mm}$ were not significantly different from each other ( $p$-value $=0.78$ ). For the 2020 study period, replication $3 \mathrm{had}$ a number of $D_{r w}$ greater than $170 \mathrm{~mm}$ (Table 3). The linear equation relationship between $D_{r w}$ and $\Delta T$ for replication 3 was statistically significant ( $\mathrm{p}$-value $<0.05$ ). Replicates 1 and 
Table 3 The range of soil water depletion (Drw, in $\mathrm{mm}$ ) and the reported coefficient of determination (R2) for the relationship between the temperature differential ( $\Delta T$; canopy temperature - air temperature) and the Drw for the four replications (independently) in maize during 2018, 2019, and 2020 growing seasons. The observed standard deviation amongst four replications for $\operatorname{Drw}$ (in $\mathrm{mm}$ ) and $\Delta T$ (in ${ }^{\circ} \mathrm{C}$ ) within each study period.

\begin{tabular}{|c|c|c|c|c|c|}
\hline \multirow[t]{2}{*}{$\begin{array}{l}\text { Study } \\
\text { period }\end{array}$} & \multirow[t]{2}{*}{$\begin{array}{l}\text { Replication } \\
\text { number }\end{array}$} & \multirow[t]{2}{*}{$\begin{array}{l}\text { Range of } \\
\mathrm{D}_{r w}(\mathrm{~mm})\end{array}$} & \multirow{2}{*}{$\begin{array}{l}\text { Coefficient of } \\
\text { determination } \\
\left(\mathrm{R}^{2}\right)\end{array}$} & \multicolumn{2}{|c|}{$\begin{array}{l}\text { Standard deviation } \\
\text { among replications }\end{array}$} \\
\hline & & & & $\mathrm{D}_{\mathrm{rw}}(\mathrm{mm})$ & $\Delta \mathrm{T}\left({ }^{\circ} \mathrm{C}\right)$ \\
\hline \multirow[t]{4}{*}{2018} & Rep 1 & $4-50$ & 0.00 & \multirow[t]{4}{*}{26.59} & \multirow[t]{4}{*}{1.69} \\
\hline & Rep 2 & -4 to 92 & 0.01 & & \\
\hline & Rep 3 & $23-115$ & 0.00 & & \\
\hline & Rep 4 & $14-72$ & 0.01 & & \\
\hline \multirow[t]{4}{*}{2019} & Rep 1 & 100-188 & $0.41^{*}$ & \multirow[t]{4}{*}{50.63} & \multirow[t]{4}{*}{1.37} \\
\hline & Rep 2 & $37-137$ & 0.04 & & \\
\hline & Rep 3 & $22-120$ & 0.01 & & \\
\hline & Rep 4 & $21-188$ & $0.13^{*}$ & & \\
\hline \multirow[t]{4}{*}{2020} & Rep 1 & $55-168$ & 0.10 & \multirow[t]{4}{*}{45.89} & \multirow[t]{4}{*}{2.41} \\
\hline & Rep 2 & $115-165$ & 0.15 & & \\
\hline & Rep 3 & $111-209$ & $0.56^{*}$ & & \\
\hline & Rep 4 & 33-112 & 0.01 & & \\
\hline
\end{tabular}

* Along with the coefficient of determination $\left(\mathrm{R}^{2}\right)$ indicates that the linear equation relationships between $\mathrm{D}_{\mathrm{rw}}$ and $\Delta \mathrm{T}$ was statistically significant ( $\mathrm{p}$-value $<0.05$ ).

2 had $D_{r w}$ values less than $170 \mathrm{~mm}$ (Table 3 ), and the linear equation relationship between $D_{r w}$ and $\Delta T$ for replications 1 and 2 were not significant ( $\mathrm{p}$-value $>0.05$ ). The results from this 3-year study indicate that at low/non-water stress conditions $\left(D_{r w}<170 \mathrm{~mm}\right), D_{r w}$ is not correlated to $\Delta T$; however, the correlation between $D_{r w}$ and $\Delta T$ tends to be significant when $D_{r w}$ values are greater than $170 \mathrm{~mm}$.

The relationship between $\Delta T$ and $D_{r w}$ was analyzed for soybean as well (Fig. 5). The sensor node station data from four replications was collected during the 2018, 2019, and 2020 growing seasons, respectively. As was observed for maize in 2018, the range of $D_{r w}$ (Table 4) values were low for soybean during 2018 growing season due to the relatively high precipitation of $272 \mathrm{~mm}\left(D_{r w}\right.$ values were less than $\left.160 \mathrm{~mm}\right)$. The linear/polynomial relationships were not statistically significant ( $p$-value $>0.05$ ) for all the four replications during the 2018 study period. The linear equation relationships for these four replications were not significantly different from each other ( $p>0.05$ ) as well. A number of the observed $D_{r w}$ values were greater than $160 \mathrm{~mm}$ for three out of four replications of the 2019 study period (Table 4) as it was comparatively drier 
Table 4 The range of soil water depletion (Drw, in $\mathrm{mm}$ ) and the reported coefficient of determination (R2) for the relationship between the temperature differential ( $\Delta T$; canopy temperature - air temperature) and the Drw for the four replications (independently) in soybean during 2018, 2019, and 2020 growing seasons along with standard deviation amongst four replications for $\operatorname{Drw}$ (in $\mathrm{mm}$ ) and $\Delta T\left(\mathrm{in}^{\circ} \mathrm{C}\right.$ ) within each study period.

\begin{tabular}{|c|c|c|c|c|c|}
\hline \multirow[t]{2}{*}{$\begin{array}{l}\text { Study } \\
\text { period }\end{array}$} & \multirow[t]{2}{*}{$\begin{array}{l}\text { Replication } \\
\text { number }\end{array}$} & \multirow[t]{2}{*}{$\begin{array}{l}\text { Range of } \\
\mathrm{D}_{r w}(\mathrm{~mm})\end{array}$} & \multirow{2}{*}{$\begin{array}{l}\text { Coefficient of } \\
\text { determination } \\
\left(\mathrm{R}^{2}\right)\end{array}$} & \multicolumn{2}{|c|}{$\begin{array}{l}\text { Standard deviation } \\
\text { among replications }\end{array}$} \\
\hline & & & & $\mathrm{D}_{\mathrm{rw}}(\mathrm{mm})$ & $\Delta \mathrm{T}\left({ }^{\circ} \mathrm{C}\right)$ \\
\hline \multirow[t]{4}{*}{2018} & Rep 1 & $34-99$ & 0.18 & \multirow[t]{4}{*}{31.63} & \multirow[t]{4}{*}{2.41} \\
\hline & Rep 2 & -3 to 52 & 0.03 & & \\
\hline & Rep 3 & -11 to 39 & 0.04 & & \\
\hline & Rep 4 & $32-117$ & 0.00 & & \\
\hline \multirow[t]{4}{*}{2019} & Rep 1 & $148-193$ & $0.35^{*}$ & \multirow[t]{4}{*}{37.35} & \multirow[t]{4}{*}{1.97} \\
\hline & Rep 2 & $116-164$ & $0.32^{*}$ & & \\
\hline & Rep 3 & $118-171$ & $0.61^{*}$ & & \\
\hline & Rep 4 & $45-115$ & 0.00 & & \\
\hline \multirow[t]{4}{*}{2020} & Rep 1 & -22 to 64 & 0.00 & \multirow[t]{4}{*}{59.38} & \multirow[t]{4}{*}{1.43} \\
\hline & Rep 2 & \multicolumn{2}{|c|}{$37-1860.34^{*}$} & & \\
\hline & Rep 3 & \multicolumn{2}{|l|}{$45-1570.10$} & & \\
\hline & Rep 4 & \multicolumn{2}{|l|}{ 108-175 0.34* } & & \\
\hline
\end{tabular}

* Along with the coefficient of determination $\left(\mathrm{R}^{2}\right)$ indicates that the linear equation relationships between $\mathrm{D}_{\mathrm{rw}}$ and $\Delta \mathrm{T}$ was statistically significant $(\mathrm{p}$-value $<0.05)$.

than the study period of 2018. Replications 1,2 , and 3 reported 90 percentile of the $D_{r w}$ values greater than $160 \mathrm{~mm}$, and the linear equation relationships between $\Delta T$ and $D_{r w}$ were statistically significant for these three replicates ( $p$-value $<0.05$ ). In addition, the linear relationships for the replications $(1,2$, and 3$)$ were not different from each other significantly ( $\mathrm{p}>0.05)$. The coefficient of determination $\left(\mathrm{R}^{2}\right)$ between $\Delta T$ and $D_{r w}$ for the relationship at higher $D_{r w}$ was $0.35,0.32$, and 0.61 for the replications 1, 2, and 3 during the 2019 growing season (Table 4) while for replication 4 was less than 0.01 . For the year 2020, a number of the observed $D_{r w}$ values were greater than $160 \mathrm{~mm}$ for two out of four replications (replications 2 and 4). The linear equation relationships between $\Delta T$ and $D_{r w}$ were statistically significant for these two replicates (p-value $<0.05$ ), and they were not significantly different from each other ( $p$ value $=0.42$ ). For soybean, there is no significant relationship between the $\Delta T$ and $D_{r w}$ when the range in $D_{r w}$ does not include values greater than $160 \mathrm{~mm}$ (i.e., lower/no water stress). However, when $D_{r w}$ range includes values greater than $160 \mathrm{~mm}$, the $\Delta T$ tends to increase and the relationships are significant (Table 4 ). 


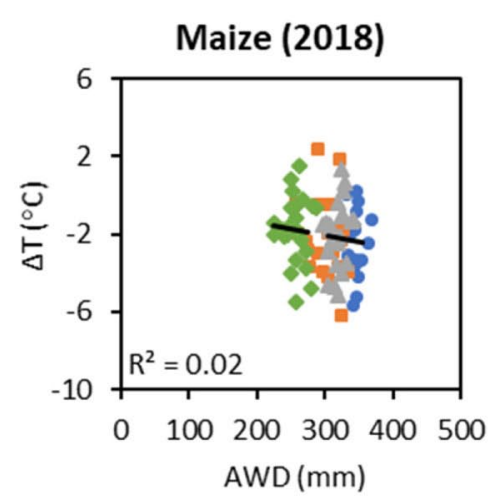

(a)

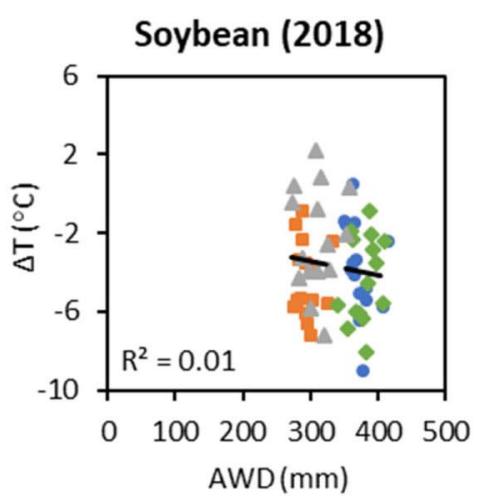

(d)

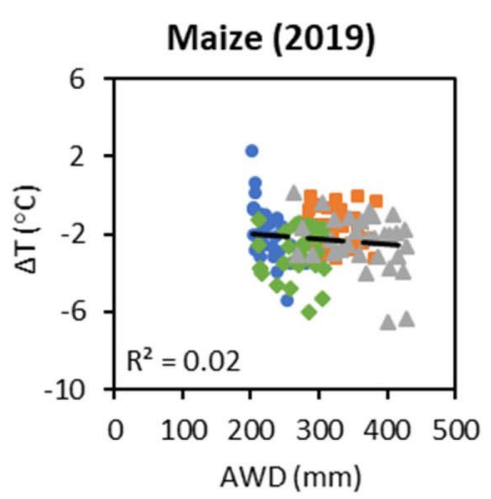

(b)

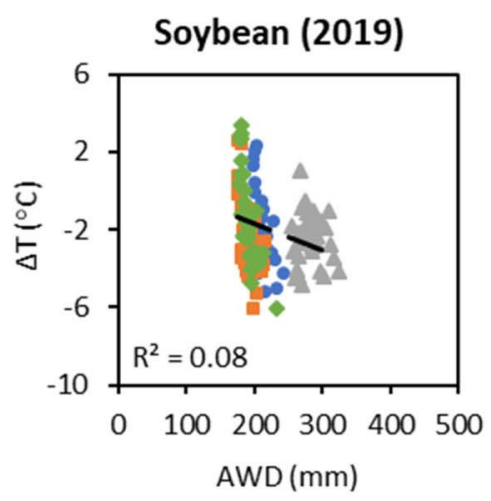

(e)

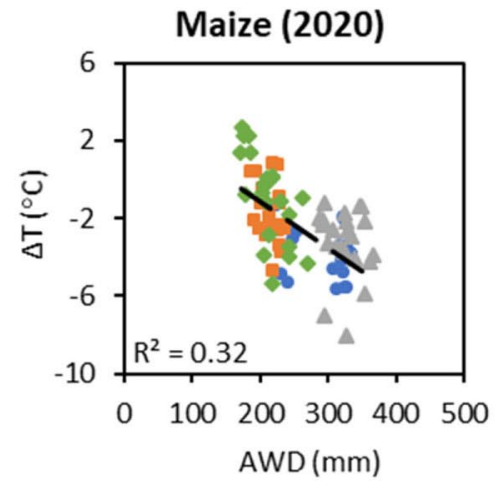

(c)

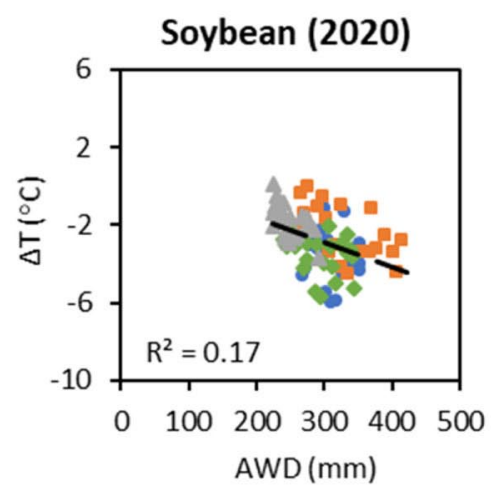

(f)

- Replication $1 \backsim$ Replication $2 \diamond$ Replication $3 \Delta$ Replication 4

Fig. 6. The comparison of the temperature differential ( $\Delta T$; canopy temperature - air temperature) and the available water depth (AWD) for the four replications (pooled) in maize (a, b, and c) and soybean (d, e, and f), respectively during the 2018, 2019, and 2020 study periods.

The relationship between $\Delta T$ and $A W D$ was analyzed for maize and soybean (Fig. 6). The sensor node station data from maize and soybean amongst four replications during 2018, 2019, and 2020 growing seasons was assessed. During the 2018 study period, the linear/polynomial relationships between $\Delta T$ and $A W D$ were not statistically significant ( $p$-value $>0.05$ ) for all the four replications in maize and for three out of four replications in soybean. Similarly, the linear/polynomial relationships were statistically significant $(\mathrm{p}<0.05)$ for replications 1 and 4 in maize; and replications 1, 2, and 3 during the 2019 growing season. The linear equation relationship was statistically significant for replication 3 in maize; and for replications 2 and 4 in soybean during the 2020 
growing season. The relationships between $\triangle T$ and $A W D$ for each replication in maize and soybean were similar to the relationships between $\Delta T$ and $D_{r w^{*}}$ However, the relationship between $\Delta T$ and $D_{r w}$ was stronger and the uncertainty in the determination of $D_{r w}$ is lesser than the uncertainty in the determination of AWD (Singh et al., 2020).

\subsection{Crop water stress index}

The non-water-stressed and water stressed baselines were developed by relating the $\Delta T$ with VPD (Eq. 7) as outlined by Idso et al. (1981a). However, the standard sampling and calculation guidelines as suggested by (Gardner et al., 1992) were noted and used while determining the baselines for maize and soybean. The lower and upper baselines for maize (Fig. 7a) were determined using the combined dataset of $\Delta T$ values of the four replications from the three growing seasons. The equation for the lower (non-water stressed) baseline of maize was reported $\left(d T_{L L}=T_{c}\right.$ $-T_{a}=-1.29 \times V P D-1.10, \mathrm{R}^{2}=0.72$ ). Based on the observations for waterstressed conditions in Fig. $7 \mathrm{a}$, the constant of $-1{ }^{\circ} \mathrm{C}$ was used as the upper baseline for maize. The lower and upper baselines for soybean were determined using the combined dataset of $\Delta T$ values of the four replications from 2018, 2019, and 2020, respectively (Fig. 7b). The equation for the lower baseline for soybean under non-water stressed conditions

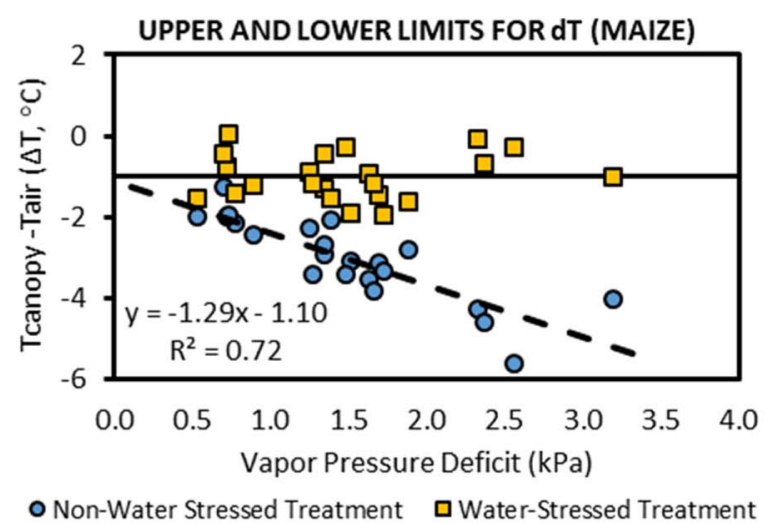

(a)

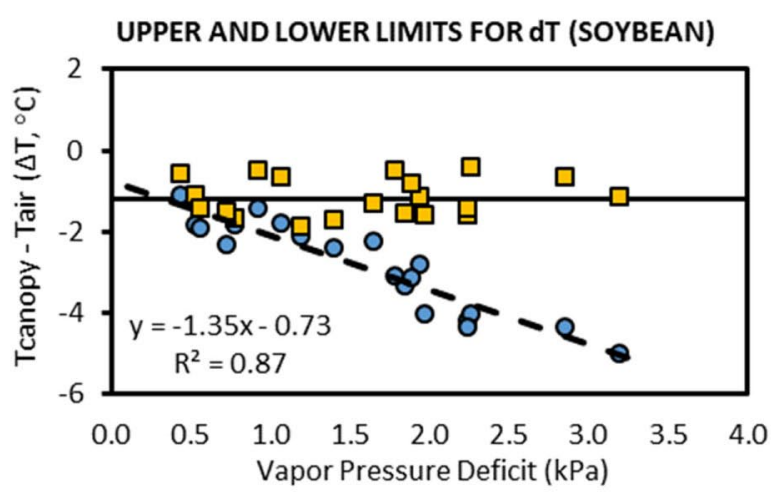

o Non-Water Stressed Treatment $\square$ Water-Stressed Treatment

(b)

Fig. 7. The relationship between the $\Delta \mathrm{T}$ (canopy temperature - air temperature) and the vapor pressure deficit (VPD) for maize (a) and soybean (b) based on 2018, 2019, and 2020 growing seasons. The non-water stressed and water-stressed baselines for maize and soybean were developed. 
had a strong relationship with VPD $\left(d T_{L L}=T_{c}-T_{a}=-1.35 \times V P D-0.73\right.$, $\left.\mathrm{R}^{2}=0.87\right)$. A constant of $-1.2^{\circ} \mathrm{C}$ was used as the upper baseline for soybean under water-stressed conditions based on the observations given in Fig. 7b. Based on the atmospheric, crop, and soil water conditions, it is occasionally possible for $\Delta \mathrm{T}$ values to be greater than the upper baseline value (i.e., $\Delta T>-1{ }^{\circ} \mathrm{C}$ for maize, $\Delta T>-1.2^{\circ} \mathrm{C}$ for soybean), so that the CWSI can be greater than 1 .

CWSI values for maize and soybean were estimated at different growth stages (from late vegetative to early maturity) for the noncloudy/ non-precipitation days during 2018, 2019, and 2020 growing seasons. The CWSI values were calculated during the afternoon (at $1500 \mathrm{~h}, \mathrm{CDT}$ ) consistently for all the replications for maize and soybean for three growing seasons when the crop canopy was $80 \%$ or greater cover (i.e., from July to mid-September) to minimize the effect of change of canopy structure on the canopy temperature readings. The CWSI values for soybean were lower during the middle part of the study periods of 2018, 2019 and 2020 and the values were higher during the latter part of the study periods. The CWSI values for maize were higher during middle part of the study period for 2018 and the latter part of the study periods of 2019 and 2020. Fig. 8 depicts the variation in CWSI values for four replications of maize and soybean for the 2018, 2019, and 2020 study periods. The CWSI value of less than 0.1 indicated a small amount of water stress, and the CWSI values within the range of 0.3-0.6 represent moderate stress (DeJonge et al., 2015). CWSI values of more than 0.8 show that the crop is under high/severe stress. Since, the lower baseline for CWSI was developed for afternoon hours under ideal conditions, the applicability of CWSI is limited to a short window of time under certain ideal conditions such as clear-sky solar radiation. CWSI has been one of the indices for evaluating crop stress response to water deficit since its development (Idso et al., 1981a; Jackson et al., 1981) in the early 1980s.

The individual CWSI values among the replications were taken at various growth stages (late vegetative to early maturity) and cannot be compared with each other since empirically determined CWSI is growth stage specific. Seasonal mean CWSI values were calculated as the average of CWSI values for each replication in maize and soybean for 2018 and 2019 growing seasons. Seasonal CWSI values for the maize replications ranged in value from 0.35 to 0.77 for the 2018 study period, and from 0.36 to 0.80 for the 2019 study period. The seasonal mean CWSI 

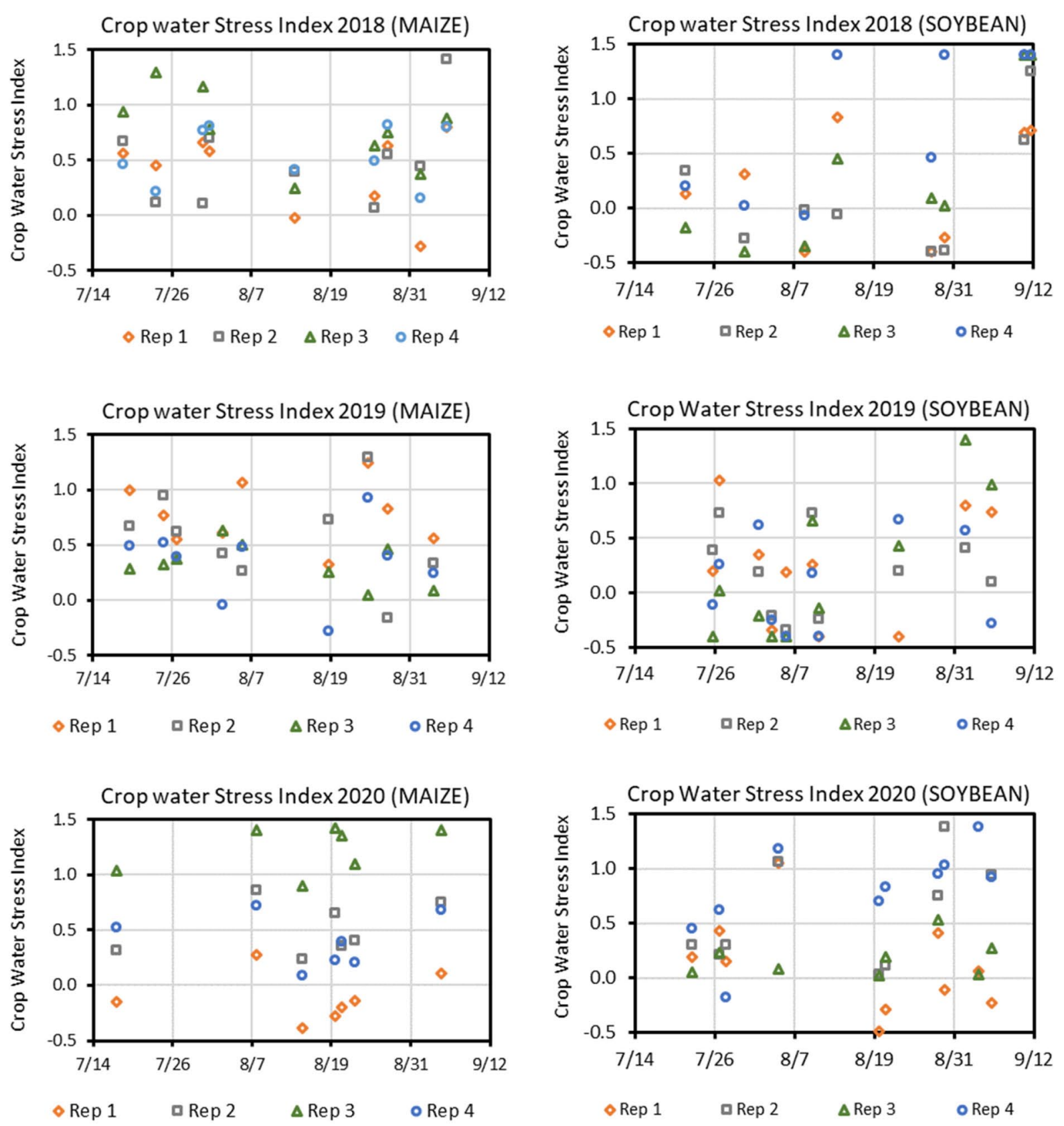

Fig. 8. The CWSI values for maize and soybean at various growth stages during the 2018, 2019, and 2020 growing seasons. The CWSI values were determined from the non-stressed and the stressed baselines for canopy stress. 


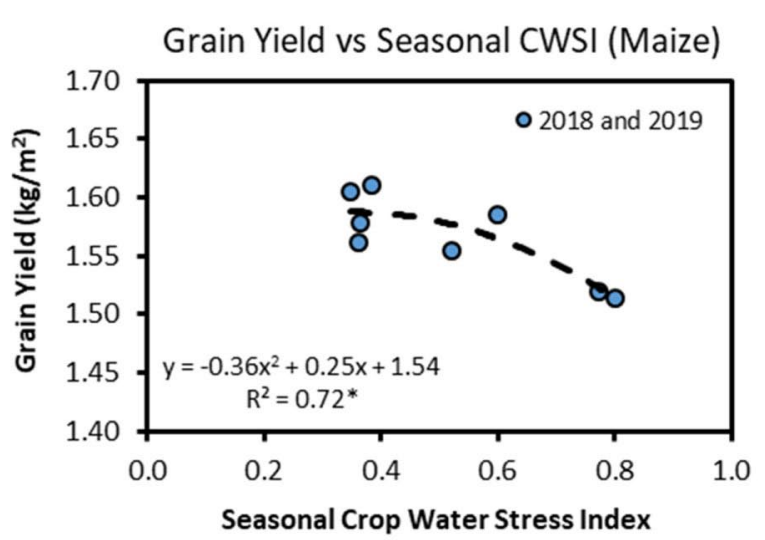

(a)

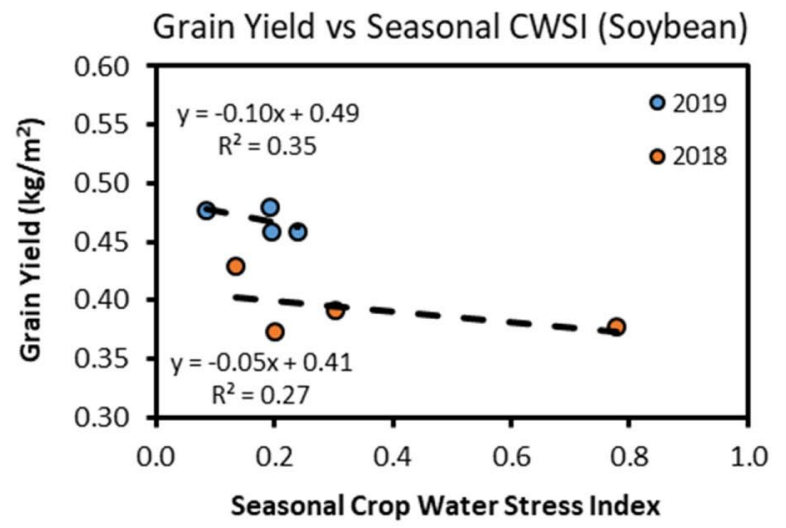

(b)

Fig. 9. (a) Maize grain yields $\left(\mathrm{Y}, \mathrm{kg} \mathrm{m}^{-2}\right)$ as a polynomial function of the seasonal mean crop water stress index, CWSI, (X) for each replication during 2018 and 2019 growing seasons. (b) Soybean grain yields $\left(\mathrm{Y}, \mathrm{kg} \mathrm{m}^{-2}\right)$ as a linear function of the seasonal mean crop water stress index, CWSI, (X) for each replication separately for 2018 and 2019 growing seasons. An asterisk [*] along with the coefficient of determination $\left(\mathrm{R}^{2}\right)$ indicates that the polynomial equation relationship between grain yield and seasonal crop water index (a) was statistically significant ( $p$-value $<0.05$ ).

values for the soybean replications ranged in value from 0.13 to 0.78 for 2018, and from 0.08 to 0.24 for 2019. Following the procedures outlined in Irmak et al. (2000), the seasonal CWSI values were correlated with the average yield $\left(\mathrm{kg} \mathrm{m}^{-2}\right)$ of the plots surrounding the sensor node location for maize and soybean. A polynomial equation [yield (in $\mathrm{kg} \mathrm{m}^{-2}$ ) $=-$ $0.36 \times(\mathrm{CWSI})^{2}+0.25 \times \mathrm{CWSI}+1.57 ; \mathrm{R}^{2}=0.72^{*} ; \mathrm{p}$-value $\left.=0.03\right]$ described the maize crop yield as a function of mean seasonal CWSI for 2018 and 2019 study periods across eight replications (Fig. 9). However, a linear equation described the relationship between seasonal mean CWSI and average yield in soybean for each study period (2018 and 2019) separately. The results indicate that maize and soybean yield decreases with the increase in CWSI.

\section{Discussion}

The CWSI determined from a theoretical based approach has been related to the root zone water, but not uniquely related (Jackson et al., 
1981). The results from our study investigating the relation between $\Delta T$ and $D_{r w}$ indicate a statistically significant relation for maize and soybean when $D_{r w}$ values are high. Similar findings have been reported by others. Taghvaeian et al. (2014) found out CWSI was unrelated to soil water deficit until a deficit > $90 \mathrm{~mm}$ was reached, Lacape et al. (1998) found values of cotton CWSI did not change significantly until about half of total available water was depleted by crop roots, and Barnes et al. (2000) found a correlation $\left(\mathrm{R}^{2}=0.39\right)$ between the CWSI and percent depletion of soil water. In addition, Taghvaeian et al. (2012) investigated the relationship between the maize CWSI and $\theta_{v}$ of the top $5 \mathrm{~cm}$ layer of clay-loam textured soil in a semi-arid climate in northeastern Colorado and found that there was a high correlation between CWSI and $\theta_{v}$; the CWSI increased with decreasing $\theta_{v^{*}}$. The relationship between CWSI and $\theta_{v}$ was best described by a second order polynomial equation. Furthermore, Candogan et al. (2013) investigated the relationship of CWSI and crop evapotranspiration (ET ${ }_{c}$ a function of $D_{r w}$ ) for soybean in sub-humid climatic conditions and found a high correlation between CWSI and ET ${ }_{c}$ and a statistically significant relationship using a second order polynomial equation, indicating $\mathrm{ET}_{\mathrm{c}} \mathrm{de}$ creased with increasing CWSI.

The results from our study were coherent to the findings of DeJonge et al. (2015), Nielsen and Anderson (1989), Taghvaeian et al. (2014, 2012) and attest to the reliability of our study's finding; most notable is an increasing trend for the $\Delta T$ with increasing $D_{r w}$ at higher ranges of $D_{r w}$. However, the observed relationship between $\Delta T$ and $D_{r w}$ was reported to be a single order polynomial equation. The results of Chávez (2015) suggested that canopy temperature indeed can be used to quantify the degree of crop water stress with a newly developed soil water stress index (a function of $D_{r w}$ ). In the future, innovative approaches to predict soil water content from canopy temperature need to be explored as, demonstrated here, canopy temperature contains qualitative information concerning soil water, and are responsive indicators of plant condition.

The continuous use of crop canopy temperature (from infrared thermometry) and soil water status can be an effective tool to monitor and quantify water stress and design an irrigation prescription based on the observed response. The CWSI has been the most commonly used index since its inception in the early 1980s (Idso et al., 1981a; Jackson et al., 1981) where they considered the energy balances of non-stressed and 
completely stressed crop canopies where theoretically, the canopy resistance of a non-stressed crop would be zero and that of a completely stressed crop would be infinite. Later, Gardner et al. (1992) pointed out that the transportability of the developed baseline to other locations is limited by the VPD range within which the baseline is developed. In our study, the baselines were developed within the VPD range of 0-3.5 kPa. However, Nielsen (1990) found that unstressed baseline developed elsewhere did not apply to different conditions while applying the empirical CWSI to soybeans. Therefore, it was concluded that a location specific non-stressed baseline should be developed for producers willing to use the empirical CWSI.

Our results showed that maize and soybean yield decreased as the CWSI increased and the relationship was best described with a second order polynomial equation for maize and single order polynomial equation for soybean. Researchers in the past have demonstrated that the yield decreased with the increase in CWSI. Reginato (1983) and Howell et al. (1984) observed linear relationships between yield and average CWSI for cotton; Idso et al. (1981b) and Abdul-Jabbar et al. (1985) found a linear relationship for alfalfa; Tubaileh et al. (1986) for spring barley; Irmak et al. (2000) reported a second-order polynomial equation for maize; and Candogan et al. (2013) found an exponential equation for soybean. Based on the results from this study, it is clearly evident that there is yield loss for maize after the seasonal mean CWSI exceeds 0.3 . However, we cannot conclude that this seasonal CWSI value should be used for timing of irrigations for maize because irrigation scheduling was not tested using the CWSI value. Since $D_{r w}$ is correlated with $\Delta T$ at higher ranges of $D_{r w}$ and there is yield loss at higher ranges of CWSI, the application of IRT-based approach in assessing $\Delta T$ is for a potential method to be used in deficit irrigation.

The advantage of CWSI (compared to simply using the $\Delta T$ ) is that it accounts for not only air temperature but also VPD and its impact on ET and plant cooling. However, some researchers have stated that the applicability of CWSI could be limiting for farmers because of its complexity (Kacira et al., 2002). Furthermore, Payero and Irmak (2006) concluded that lower baselines for maize and soybean were functions of plant canopy height, VPD, solar radiation and wind speed; and upper baselines were functions of solar radiation and wind speed for soybean and solar radiation, crop height, and wind speed for maize. Accounting for these 
factors would make the CWSI too cumbersome for farmers to use. The non-water stressed and water stressed baselines have been developed for maize under a wide range of climatic conditions, from semi-arid (DeJonge et al., 2015; Irmak et al., 2000; Taghvaeian et al., 2012) to sub-humid/sub-tropical (Kar and Kumar, 2010). The intercept of the non-water stressed baseline for maize developed in our study was a negative constant value (-1.37). Similarly, Kar and Kumar (2010) reported a negative constant value (-3.77) for the intercept of non-water stressed baseline in a similar surrounding environment, i.e. sub-humid climate. However, researchers in the semi-arid climate have observed a positive constant intercept value $(>0)$ for the non-water stressed baseline. A theoretical approach to determine the equations for non-water stressed and water stressed baselines was used by Kar and Kumar (2010) in a sub-humid environment for maize. The constant value of $-1{ }^{\circ} \mathrm{C}$ was calculated for the water stressed (upper) baseline which is same as what was observed in the current study. The relationship of non-water stressed baseline $(\Delta \mathrm{T}=-1.10 \times V P D-3.77)$ determined by Kar and Kumar (2010) was similar to the results of our study $(\triangle T=-1.29 \times V P D-1.10)$ in a way that both the coefficients of the linear equation were negative and the slopes were smaller. Additional requirement of weather dataset, additional computation (baselines), and ideal sky (non-cloudy) conditions tends to make it complicated as it involves numerous measurements and rigorous calculations. Additionally, prior analysis indicates that the $\Delta T$ could be highly correlated with the physiological stress measurements such as $D_{r w}$ at higher ranges of $D_{r w}$. Because the $\Delta T$ is correlated with the CWSI, it could be used as CWSI without the need of actually measuring CWSI, but this needs additional research to verify/validate some of the findings of this and similar studies. Although the indices shown in this study such as the stressed and non-stressed baselines, and CWSI can be most informative about the timing of irrigation application, it has a limited applicability to farmers because of its complexity.

\section{Conclusion}

A field experiment was conducted in a sub-humid climate during 2018, 2019, and 2020 growing seasons over maize and soybean to investigate the relationship between the $\Delta T\left(T_{c}-T_{a}\right)$ and $D_{r w}$ (for top 1 profile) after 
$80 \%$ or more canopy cover was achieved. Non-water stressed and water stressed baselines for quantification of CWSI were also developed. There is no unique relationship between the $\Delta T$ and $D_{r w}$ at lower $D_{r w}$ ranges for maize or soybean (i.e., $D_{r w}<170 \mathrm{~mm}$ for maize; and $D_{r w}<160$ mm for soybean). However, at higher ranges of $D_{r w}$ (i.e., $D_{r w}>170 \mathrm{~mm}$ for maize; and $D_{r w}>160 \mathrm{~mm}$ for soybean), the $\Delta T$ tends to increase with the increase in $D_{r w^{*}}$. The relationships between $\triangle T$ and $A W D$ for each replication in maize and soybean were similar to the relationships between $\Delta T$ and $D_{r w^{\prime}}$. However, the relationships between $\Delta T$ and $D_{r w}$ were stronger and the uncertainty in determination of $D_{r w}$ is less.

The upper (water stressed) and lower (non-water stressed) baselines for maize and soybean were developed based on the dataset from three growing seasons for this sub-humid location and then CWSI values were quantified at various growth stages. To the best of the authors' knowledge, this research study is the first to develop upper and lower baselines for east-central Nebraska for maize and soybean. The coefficient of determination $\left(\mathrm{R}^{2}\right)$ for the lower baselines for maize and soybean were 0.73 and 0.89 . The constant of $-1.0^{\circ} \mathrm{C}$, and $-1.2^{\circ} \mathrm{C}$ was used as the upper baseline for maize, and soybean, respectively under water stressed conditions. After the quantification of CWSI for maize and soybean at various growth stages (late development to early maturity) for 2018 and 2019 study periods, the seasonal CWSI values were related with the average yield for the two growing seasons for the different node stations. Our results showed that the maize and soybean yield decreased as the CWSI increased and the relationship was best described with a second order polynomial equation for maize and single order polynomial equation for soybean. While the results indicate a threshold CWSI could be used for timing of irrigation application as irrigation scheduling, this was not tested since it was beyond the scope of this study. The results indicate a potential application of IRTs for deficit irrigation scheduling rather than full irrigation in a sub-humid climate under given field conditions. The authors recommend future studies aim to investigate if the determination of $D_{r w}$ and/or $\Delta T$ is more promising and practical for efficient allocation of water resources and if a threshold CWSI could be used for timing of irrigation to prevent yield loss.

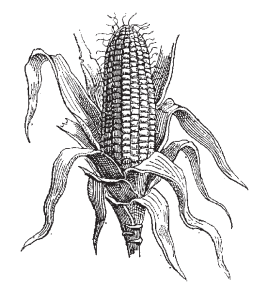


Competing Interests The authors declare they have no known competing financial interests or personal relationships that could have appeared to influence the work reported in this paper.

Acknowledgments The funding for this research was provided by a grant from the USDA NIFA Agricultural and Food Research Initiative (Award Number 2017- 6702126249) and Graduate Student Support from the Robert B. Daugherty Water for Food Global Institute at the University of Nebraska. Additional support was received from the Hatch Act (USDA NIFA, Accession Number 1009760) and the Department of Biological Systems Engineering at the University of Nebraska-Lincoln. The authors thank Dr. Burdette Barker for input in the experimental design; Alan L. Boldt, Jake Richardson, Eric Wilkening, Divine Kantarama, Troy Nelson, Tony Ruhinda, Joviale Uwase, Kate Yang, and Arena-Ezzati See for assistance with the data collection; Mr. Mark Schroeder and his team from the University of Nebraska's Eastern Nebraska Research and Extension Center for their cooperation and help with field operations; and Dr. Christine Booth and Suresh Pradhyun Kashyap for reviewing earlier versions of the manuscript. Weather data were provided by the Nebraska Mesonet and the Nebraska State Climate Office through the High Plains Regional Climate Center.

\section{References}

Abdul-Jabbar, A.S., Lugg, D.G., Sammis, T.W., Gay, L.W., 1985. Relationships between crop water stress index and alfalfa yield and evapotranspiration. Trans. Am. Soc. Agric. Eng. 28, 454-461.

Barker, J.B., Heeren, D.M., Daugherty, R.B., Neale, C.M.U., Rudnick, D.R., 2018. Evaluation of variable rate irrigation using a remote-sensing-based model. Agric. Water Manag. 203, 63-74. https://doi.org/10.1016/j.agwat.2018.02.022

Barnes, E.M., Clarke, T.R., Richards, S.E., Colaizzi, P.D., Haberland, J., Kostrzewski, M., Waller, P., Choi, C., Riley, E., Thompson, T., Lascano, R.J., Li, H., Moran, M.S., 2000. Coincident detection of crop water stress, nitrogen status, and canopy density using ground-based multispectral data. In: Proceedings of the 5th International Conference on Precision Agriculture and Other Resource Management, Bloomington. Madison, Wisc.

Bhatti, S., Heeren, D.M., Barker, J.B., Neale, C.M.U., Woldt, W.E., Maguire, M.S., Rudnick, D.R., 2020. Site-specific irrigation management in a sub-humid climate using a spatial evapotranspiration model with satellite and airborne imagery. Agric. Water Manag. 230, 1-13. https://doi.org/10.1016/j.agwat.2019.105950

Candogan, B.N., Sincik, M., Buyukcangaz, H., Demirtas, C., Goksoy, A.T., Yazgan, S., 2013. Yield, quality and crop water stress index relationships for deficit-irrigated soybean [Glycine max (L.) Merr.] in sub-humid climatic conditions. Agric. Water Manag. 118, 113-121. https://doi.org/10.1016/j.agwat.2012.11.021

Chávez, J.L., 2015. Using canopy temperature as an indicator of plant stress. In: Proceedings of the 26th Annual Central Plains Irrigation Conference. pp. 61-70. 
Colaizzi, P.D., Barnes, E.M., Clarke, T.R., Choi, C.Y., Waller, P.M., 2003. Estimating soil moisture under low frequency surface irrigation using crop water stress index. J. Irrig. Drain. Eng. 129, 27-35. https://doi.org/10.1061/ (ASCE)0733-9437(2003)129:1(27)

Datta, S., Taghvaeian, S., Ochsner, T.E., Moriasi, D., Gowda, P., Steiner, J.L., 2018. Performance assessment of five different soil moisture sensors under irrigated field conditions in Oklahoma. Sensors 18, 1-17. https://doi.org/10.3390/ $\underline{\text { s18113786 }}$

DeJonge, K.C., Taghvaeian, S., Trout, T.J., Comas, L.H., 2015. Comparison of canopy temperature-based water stress indices for maize. Agric. Water Manag. 156, 5162. https://doi.org/10.1016/i.agwat.2015.03.023

Doorenbos, J., Kassam, A.H., 1979. Yield response to water. FAO Irrig. Drain. Pap. No. 33. FAO, Rome.

Ehrler, W.L., 1973. Cotton leaf temperatures as related to soil water depletion and meteorological factors 1. Agron. J. 65, 404-409. https://doi.org/10.2134/agronj1 973.00021962006500030016x

Ehrler, W.L., Idso, S.B., Jackson, R.D., Reginato, R.J., 1978a. Wheat canopy temperature: relation to plant water potential. Agron. J. 70, 251-256. https://doi. org/10.2134/agronj1978.00021962007000020010x

Ehrler, W.L., Idso, S.B., Jackson, R.D., Reginato, R.J., 1978b. Diurnal changes in plant water potential and canopy temperature of wheat as affected by drought 1 . Agron. J. 70, 999-1004. https://doi.org/10.2134/agronj1978.00021962007000060027x

Evett, S.R., O'Shaughnessy, S.A., Andrade, M.A., Kustas, W.P., Anderson, M.C., Schomberg, H.H., Thompson, A.I., 2020. Precision agriculture and irrigation - Current U.S. perspectives. T ASABE 63, 57-67. https://doi.org/10.13031/ trans.13355

Fuchs, M., Tanner, C.B., 1966. Infrared thermometry of vegetation. Agron. J. 58, 5976001. https://doi.org/10.2134/agronj1966.00021962005800060014x

Gardner, B.R., Blad, B.L., Garrity, D.P., Watts, D.G., 1981. Relationships between crop temperature, grain yield, evapotranspiration and phenological development in two hybrids of moisture stressed sorghum. Irrig. Sci. 2, 213-224. https://doi. org/10.1007/BF00258375

Gardner, B.R., Nielsen, D.C., Shock, C.C., 1992. Infrared thermometry and the crop water stress index. II. Sampling procedures and interpretation. J. Prod. Agric. 5, 466-475.

Geerts, S., Raes, D., 2009. Deficit irrigation as an on-farm strategy to maximize crop water productivity in dry areas. Agric. Water Manag. 96, 1275-1284. https://doi. org/10.1016/j.agwat.2009.04.009

Hellerstein, D., Vilorio, D., Ribaudo, M., 2019. Agricultural Resources and Environmental Indicators, 2019. U.S. Dep. Agric. Econ. Res. Serv. 50.

Howell, T.A., Hatfield, J.L., Yamada, H., Davis, K.R., 1984. Evaluation of cotton canopy temperature to detect crop water stress. Trans. Am. Soc. Agric. Eng. 27, 84-88. https://doi.org/10.13031/2013.32740 
Huang, J., McBratney, A.B., Minasny, B., Triantafilis, J., 2017. Monitoring and modelling soil water dynamics using electromagnetic conductivity imaging and the ensemble Kalman filter. Geoderma 285, 76-93. https://doi.org/10.1016/j. geoderma.2016.09.027

Idso, S.B., Jackson, R.D., Pinter, P.J., Reginato, R.J., Hatfield, J.L., 1981a. Normalizing the stress-degree-day parameter for environmental variability. Agric. Meteorol. 24, 45-55. https://doi.org/10.1016/0002-1571(81)90032-7

Idso, S.B., Reginato, R.J., Reicosky, D.C., Hatfield, J.L., 1981b. Determining soil-induced plant water potential depressions in alfalfa by means of infrared thermometry 1 . Agron. J. 73, 826-830. https://doi.org/10.2134/agronj1981.0002196200730005 $\underline{0019 x}$

Irmak, S., Haman, D.Z., Bastug, R., 2000. Determination of crop water stress index for irrigation timing and yield estimation of corn. Agron. J. 92, 1221-1227. https:// doi.org/10.2134/agronj2000.9261221x

Jackson, R.D., Idso, S.B., Reginato, R.J., Pinter, P.J., 1981. Canopy temperature as a crop water stress indicator. Water Resour. Res. 17, 1133-1138. https://doi. org/10.1029/WR017i004p01133

Jackson, R.D., Reginato, R.J., Idso, S.B., 1977. Wheat canopy temperature: a practical tool. Water Resour. Res. 13.

Kacira, M., Ling, P.P., Short, T.H., 2002. Establishing Crop Water Stress Index (CWSI) threshold values for early, non-contact detection of plant water stress. Trans. ASAE 45, 775-780.

Kar, G., Kumar, A., 2010. Energy balance and crop water stress in winter maize under phenology-based irrigation scheduling. Irrig. Sci. 28, 211-220. https://doi. org/10.1007/s00271-009-0192-x

Konikow, L.F., 2013. Groundwater Depletion in the United States (1900-2008). Sci. Investig. Rep. 2013-5079, 63.

Kukal, M.S., Irmak, S., Sharma, K., 2020. Development and application of a performance and operational feasibility guide to facilitate adoption of soil moisture sensors. Sustaintainbility 12. https://doi.org/10.3390/su12010321

Lacape, M.J., Wery, J., Annerose, D.J.M., 1998. Relationships between plant and soil water status in five field-grown cotton (Gossypium hirsutum L.) cultivars. F. Crop. Res. 57, 29-43. https://doi.org/10.1016/S0378-4290(97)00111-1

Lea-Cox, J.D., Williams, J., Mellano, M.A., 2018. Optimising a sensor-based irrigation protocol for a large-scale cut-flower operation in southern California. Acta Hortic. 1197, 219-225. https://doi.org/10.17660/ActaHortic.2018.1197.29

Lo, T., Heeren, D.M., Mateos, L., Luck, J.D., Martin, D.L., Miller, K.A., Barker, J.B., Shaver, T.M., 2017. Field characterization of field capacity and root zone available water capacity for variable rate irrigation. Appl. Eng. Agric. Am. Soc. Agric. Biol. Eng. 33, 559-572. https://doi.org/10.13031/aea.11963

Miller, K.A., Luck, J.D., Heeren, D.M., Lo, T., Martin, D.L., Barker, J.B., 2017. A geospatial variable rate irrigation control scenario evaluation methodology based on mining root zone available water capacity. Precis. Agric. 19, 666-683. https://doi. org/10.1007/s11119-017-9548-z 
Neale, C.M.U., Geli, H.M.E., Kustas, W.P., Alfieri, J.G., Gowda, P.H., Evett, S.R., Prueger, J.H., Hipps, L.E., Dulaney, W.P., Chávez, J.L., French, A.N., Howell, T.A., 2012. Soil water content estimation using a remote sensing based hybrid evapotranspiration modeling approach. Adv. Water Resour. 50,152-161. https://doi.org/10.1016/j. advwatres.2012.10.008

Nielsen, D.C., 1990. Scheduling irrigations for soybeans with the crop water stress index (CWSI). F. Crop. Res. 23, 103-116.

Nielsen, D.C., Anderson, R.L., 1989. Infrared thermometry to measure single leaf temperatures for quantification of water stress in sunflower. Agron. J. 81, 840-842.

O'Shaughnessy, S.A., Andrade, M.A., Evett, S.R., 2017. Using an integrated crop water stress index for irrigation scheduling of two corn hybrids in a semi-arid region. Irrig. Sci. 35, 451-467. https://doi.org/10.1007/s00271-017-0552-x

O'Shaughnessy, S.A., Evett, S.R., Colaizzi, P.D., Howell, T.A., 2012. A crop water stress index and time threshold for automatic irrigation scheduling of grain sorghum. Agric. Water Manag. 107, 122-132. https://doi.org/10.1016/j.agwat.2012.01.018

Ojo, E.R., Bullock, P.R., Fitzmaurice, J., 2014. Field performance of five soil moisture instruments in heavy clay soils. Soil Sci. Soc. Am. J. 79, 20-29. https://doi. org/10.2136/sssaj2014.06.0250

Payero, J.O., Irmak, S., 2006. Variable upper and lower crop water stress index baselines for corn and soybean. Irrig. Sci. 25, 21-32. https://doi.org/10.1007/ s00271-006-0031-2

Peters, R.T., Evett, S.R., 2008. Automation of a center pivot using the temperaturetime-threshold method of irrigation scheduling. J. Irrig. Drain. Eng. 134 (3), 286291. https://doi.org/10.1061/ASCE 0733-9437(2008) 134:3(286)

Playán, E., Salvador, R., López, C., Lecina, S., Dechmi, F., Zapata, N., 2014. Solid-set sprinkler irrigation controllers driven by simulation models: opportunities and bottlenecks. J. Irrig. Drain. Eng. 140, 1-10. https://doi.org/10.1061/(ASCE) IR.1943-4774.0000653

Reginato, R.J., 1983. Field quantification of crop water stress. Trans. ASAE 26, 772-775.

Rudnick, D.R., Djaman, K., Irmak, S., 2015. Performance analysis of capacitance and electrical resistance-type soil moisture sensors in a silt loam soil. Trans. ASABE 58, 649-665. https://doi.org/10.13031/trans.58.10761

Saxton, K.E., Rawls, W.J., 2006. Soil water characteristic estimates by texture and organic matter for hydrologic solutions. Soil Sci. Soc. Am. J. 70, 1569-1578. https://doi.org/10.2136/sssaj2005.0117

Shulski, M., Cooper, S., Roebke, G., Al Dutcher, 2018. The Nebraska Mesonet: technical overview of an automated state weather network. J. Atmos. Ocean. Technol. 35, 2189-2200. https://doi.org/10.1175/JTECH-D-17-0181.1

Singh, J., Heeren, D.M., Ge, Y., Bai, G., Neale, C.M.U., Maguire, S., Bhatti, S., 2021. Sensor-based Irrigation of Maize and Soybean in East-Central Nebraska under a Sub- Humid Climate 2021 Annual International Meeting. In: Proceedings of the ASABE 2021 Annual International Meeting. American Society of Agricultural and Biological Engineers, pp. 1-12. 
Singh, J., Heeren, D.M., Rudnick, D.R., Woldt, W.E., Bai, G., Ge, Y., Luck, J.D., 2020. Soil structure and texture effects on the precision of soil water content measurements with a capacitance based electromagnetic sensor. Trans. ASABE 63, 141-152. https://doi.org/10.13031/trans.13496

Singh, J., Lo, T., Rudnick, D.R., Dorr, T.J., Burr, C.A., Werle, R., Shaver, T.M., MuñozArriola, F., 2018. Performance assessment of factory and field calibrations for electromagnetic sensors in a loam soil. Agric. Water Manag. 196, 87-98. https:// doi.org/10.1016/j.agwat.2017.10.020

Soil Survey Staff, 2020. U.S. Department of Agriculture Natural Resources Conservation Service [WWW Document]. URL http://websoilsurvey.Sc.egov.usda. gov/ (Accessed 29 June 2020).

Taghvaeian, S., Chávez, J.L., Hansen, N.C., 2012. Infrared thermometry to estimate crop water stress index and water use of irrigated maize in northeastern Colorado. Remote Sens. 4, 3619-3637. https://doi.org/10.3390/rs4113619

Taghvaeian, S., Comas, L., DeJonge, K.C., Trout, T.J., 2014. Conventional and simplified canopy temperature indices predict water stress in sunflower. Agric. Water Manag. 144, 69-80. https://doi.org/10.1016/j.agwat.2014.06.003

Tubaileh, A.S., Sammis, T.W., Lugg, D.G., 1986. Utilization of thermal infrared thermometry for detection of water stress in spring barley. Agric. Water Manag. 12, 75-85. https://doi.org/10.1016/0378-3774(86)90007-7

Varble, J.L., Chávez, J.L., 2011. Performance evaluation and calibration of soil water content and potential sensors for agricultural soils in eastern Colorado. Agric. Water Manag. 101, 93-106. https://doi.org/10.1016/j.agwat.2011.09.007

WWAP (World Water Assessment Programme), 2012. The United Nations World Water Development Report 4: Managing Water under Uncertainty and Risk, UNESCO, Paris, France. 